\title{
Pengembangan Sistem Pelatihan \\ Melalui Analisis Kesenjangan Kompetensi Arsiparis \\ di Kementerian Sekretariat Negara \\ Tahun 2021
}

$\begin{array}{lllllllll}\text { I } & \mathbf{N} & \mathbf{T} & \mathbf{I} & \mathbf{S} & \mathbf{A} & \mathbf{R} & \mathbf{I}\end{array}$

Kementerian Sekretariat Negara mengelola arsip terkait dengan Presiden dan Wakil Presiden. Arsip tersebut perlu dikelola arsiparis yang kompeten. Pembentukan arsiparis kompeten dilakukan melalui program Pengembangan Kompetensi Aparatur Sipil Negara, yang salah satu prosesnya adalah analisis kebutuhan pelatihan. Analisis kebutuhan pelatihan dilakukan melalui pendekatan analisis kesenjangan. Tujuan penelitian yaitu menganalisis level dan jenis kompetensi yang dibutuhkan dimiliki, kesenjangan antara level dan jenis kompetensi serta merancang program pelatihan sesuai kebutuhan. Penelitian menggunakan pendekatan deskriptif kuantitatif melalui metode sensus dengan responden sebanyak 46 orang. Metode penelitian yang digunakan adalah analisis deskriptif dan analisis kesenjangan kompetensi. Hasil penelitian menyatakan bahwa jenis kompetensi yang dibutuhkan arsiparis meliputi kompetensi manajerial, sosial kultural, dan teknis berkisar di level 4 - 5, jenis kompetensi yang dimiliki arsiparis berkisar di level 3 4. Terdapat kesenjangan yang signifikan di semua jenis kompetensi baik kompetensi manajerial, sosial kultural, maupun teknis, dengan besaran kesenjangan level kompetensi berkisar antara 0,13 sampai dengan 1,73. Program pelatihan yang dirancang sesuai dengan kebutuhan arsiparis dan termasuk kategori prioritas antara lain membangun integritas, bekerja dalam tim, bekerja efektif, pelayanan prima, penetapan tujuan, membangun tim efektif, komunikasi, penetapan tujuan dan umpan balik, people development, pengelolaan arsip dinamis, pengelolaan arsip statis, dan pembinaan kearsipan.

\section{$\begin{array}{llllllll}A & B & S & T & R & A & C & T\end{array}$}

The Ministry of State Secretariat manage archives related to the President and Vice President. The archives needs to be managed by a competent archivist. The formation of competent archivists is carried out through the Competency Development program for the Indonesian Civil Servants, one of the
PENULIS

Mohammad Harris Pratama, S.Pd.

Institut Pertanian Bogor mhpratama90@gmail.com

\section{KATA KUNCI}

arsiparis, kesenjangan, kompetensi

KEY WORDS

archivist, competency, gap

Submitted: 06/02/2021

Reviewed: $11 / 02 / 2021$

Accepted: 25/02/2021 
processes is a training needs analysis. Analysis of training needs is carried out through an gap analysis. The research objective is to analyze the level and types of competencies needed currently, including the level and types of competencies as well as training programs as needed. The research used a quantitative descriptive approach through the census method with 46 respondents. The research method used is descriptive analysis and gap analysis. The results of the research show that the types of competencies required by archivists include managerial, sociocultural, and technical competencies ranging from level 4 to 5, the types of competencies possessed by archivists range from level 3 - 4, there are significant gaps in all types of competencies, be it managerial, socio-cultural and technical competencies, with gap in competency levels ranging from 0.13 to 1.73 . Training programs designed in accordance with the needs of archivists and including priority categories including integrity building, team work, effective work, excellent service, goal setting, effective team building, communication, goal setting and feedback, people development training, records management, archives management, and archiving guidance.

\section{PENGANTAR}

\section{Latar Belakang Masalah}

Transparansi dan akuntabilitas kinerja pemerintahan menjadi salah satu indikator penting dari perwujudan tata kelola pemerintahan bersih dan efektif. Dalam membangun transparansi dan akuntabilitas tentunya diperlukan dokumentasi nyata sebagai buktinya. Arsip merupakan salah satu bukti konkrit dalam membuktikan implementasi transparansi dan akuntabilitas tersebut.

Sistem pendukung diperlukan untuk mengelola arsip dengan baik. Sistem tersebut mencakup antara lain tata kelola yang bagus, infrastruktur yang memadai, organisasi yang handal, dan sumber daya manusia yang kompeten.
Dari keempat hal tersebut, sumber daya manusia merupakan ujung tombak dari pengelolaan arsip itu sendiri sehingga perlu betul-betul diperhatikan.

Kementerian Sekretariat Negara (Kemensetneg) dalam hal ini selaku instansi pemerintah pusat yang bertanggungjawab atas tugas dan fungsi untuk menyediakan berbagai bentuk dukungan baik secara teknis maupun administrasi serta analisis bagi Presiden dan Wakil Presiden untuk menjalankan tugas penyelenggaraan pemerintahan negara, menyimpan banyak arsip vital dan terjaga berkenaan dengan Presiden dan Wakil Presiden. Arsip vital dan terjaga tersebut tentunya membutuhkan tata kelola yang baik dan teratur dari sumber 
Khazanah: Jurnal Pengembangan Kearsipan, 2021, Vol. 14 (2)

Tabel 1

Jumlah Pelatihan Arsiparis Periode 2017 - 2019

\begin{tabular}{|l|c|c|c|c|}
\hline \multicolumn{1}{|c|}{ Jenjang Jabatan } & 2017 & 2018 & 2019 & Jumlah Total Pelatihan \\
\hline Arsiparis Terampil & 8 & 22 & 7 & 37 \\
\hline Arsiparis Mahir & 5 & 14 & 14 & 33 \\
\hline Arsiparis Penyelia & 3 & 2 & 0 & 5 \\
\hline Arsiparis Ahli Pertama & 0 & 0 & 0 & 0 \\
\hline Arsiparis Ahli Muda & 2 & 2 & 7 & 11 \\
\hline \multicolumn{1}{|c|}{ Jumlah } & 18 & 40 & 28 & 86 \\
\hline
\end{tabular}

Sumber: Data Primer, 2021.

daya manusia yang memiliki kompetensi memadai sehingga tetap terjaga keutuhannya, salah satunya adalah jabatan fungsional tertentu (JFT) arsiparis.

Mengingat banyaknya arsip-arsip vital dan terjaga mengenai Presiden dan Wakil Presiden yang membutuhkan penanganan dan kemampuan lanjutan dengan kompetensi tertentu, maka diperlukan pendidikan dan pelatihan berkelanjutan bagi setiap arsiparis. Arsiparis Kemensetneg berupaya untuk terus mengembangkan diri dan meningkatkan kompetensi mereka.

Upaya membentuk jabatan fungsional arsiparis yang kompeten di lingkungan Kemensetneg salah satunya melalui program Pengembangan Kompetensi Aparatur Sipil Negara (PKASN). Penyelenggaraan PKASN dilakukan dengan tujuan mengisi kesenjangan kompetensi ASN baik segi kompetensi teknis, manajerial, dan sosial kultural. Salah satu bagian dari penyelenggaraan PKASN adalah menetapkan kebutuhan dan rencana pengembangan kompetensi. Salah satu proses adalah pelaksanaan kegiatan analisis kebutuhan pelatihan (AKP) yang berfungsi untuk mengidentifikasi dan memetakan pelatihan sehingga bisa tepat sasaran sesuai kebutuhan.

Berdasarkan hasil wawancara awal dengan Kepala Subbagian Penyelenggaraan Pelatihan Fungsional Kemensetneg di mana pelaksanaan pelatihan kompetensi arsiparis di lingkungan Kemensetneg belum optimal. Hal tersebut terlihat dari sebaran arsiparis yang mendapat pelatihan secara tidak merata seperti pada Tabel 1. Selain itu, sebaran jenis kompetensi sasaran pun terlihat tidak merata, seperti yang terlihat pada Tabel 2. Pelatihan kompetensi teknis mendominasi pada periode 2017 - 2019 . Mengacu pada data yang tertera dalam Tabel 1 dan Tabel 2, dapat diduga bahwa pelatihan fungsional belum optimal, salah s a t u penyebabnya a d a la h rekomendasi/usulan pelatihan 
Khazanah: Jurnal Pengembangan Kearsipan, 2021, Vol. 14 (2)

Tabel 2

Jumlah Pelatihan Berdasarkan Jenis Kompetensi Periode 2017 - 2019

\begin{tabular}{|l|c|c|c|c|}
\hline Jenis Kompetensi & 2017 & 2018 & 2019 & Total \\
\hline Manajerial & 4 & 0 & 1 & 5 \\
\hline Sosial Kulutral & 0 & 0 & 0 & 0 \\
\hline Teknis & 11 & 12 & 19 & 42 \\
\hline Jumlah & 15 & 12 & 20 & 47 \\
\hline
\end{tabular}

Sumber: Data Primer, 2021.

kompetensi tenaga fungsional arsiparis yang ada belum secara maksimal mengakomodasi kebutuhan kompetensi teknis, manajerial dan sosial kultural yang dibutuhkan, sehingga pelaksanaan program pelatihan kompetensi bagi tenaga fungsional arsiparis masih belum tepat sasaran dan tersebar secara merata. Padahal setiap tahunnya arsiparis tersebut perlu mendapat hak atas pengembangan kompetensi sekurang-kurangnya 20 jam pelajaran sebagaimana yang diamanatkan Peraturan Pemerintah Nomor 11 Tahun 2017 tentang Manajemen Pegawai Negeri Sipil (PNS).

Penjabaran tersebut menunjukkan perlunya dilakukan AKP yang dapat mengakomodasi kebutuhan kompetensi arsiparis baik secara teknis, manajerial, maupun sosial kultural yang dibutuhkan secara tepat. Salah satunya melalui pendekatan analisis kesenjangan. Diharapkan penyusunan program pengembangan kompetensi terhadap arsiparis di Kemensetneg dapat dilaksanakan secara efektif dan efisien.

\section{Rumusan Masalah}

Berdasarkan hal-hal yang telah dijabarkan sebelumnya maka dapat ditarik rumusan masalah yang dapat dikaji lebih dalam sebagaimana berikut. Pertama, bagaimana level dan jenis kompetensi yang dibutuhkan arsiparis Kemensetneg? Kedua, bagaimana level dan jenis kompetensi yang dimiliki saat ini oleh arsiparis Kemensetneg? Ketiga, bagaimana analisis kesenjangan antara level dan jenis kompetensi yang dibutuhkan dengan level dan jenis kompetensi yang dimiliki saat ini oleh arsiparis Kemensetneg? Keempat, bagaimana kebutuhan pelatihan yang sesuai dengan arsiparis Kemensetneg berdasarkan analisis kesenjangan dan prioritas pengembangan kompetensinya?

\section{Tujuan Penelitian}

Tujuan penelitian ini sebagaimana berikut. Pertama, menganalisis level dan jenis kompetensi yang dibutuhkan arsiparis Kemensetneg. Kedua, menganalisis level dan jenis kompetensi 
yang dimiliki kini oleh arsiparis Kemensetneg. Ketiga, menganalisis kesenjangan antara level dan jenis kompetensi yang dibutuhkan dengan level dan jenis kompetensi yang dimiliki oleh arsiparis Kemensetneg. Keempat, menyusun dan mendesain program pelatihan yang selaras dengan kebutuhan arsiparis Kemensetneg sesuai analisis kesenjangan dan prioritas pengembangan kompetensinya.

\section{Metodologi Penelitian}

Penelitian ini merupakan penelitian deskriptif kuantitatif. Pengambilan data primer pada penelitian ini dilakukan dengan metode sensus. Metode sensus dilakukan kepada seluruh arsiparis yang ada di lingkungan Kemensetneg sebanyak 46 orang yang terdiri dari jenjang jabatan Arsiparis Terampil, Mahir, Penyelia, Ahli Pertama, dan Ahli Muda. Tiga puluh dua atasan dari arsiparis merupakan penilai Current Competency Level (CCL) arsiparis. Dua orang pejabat di bidang kearsipan dan satu orang pejabat di Biro Sumber Daya Manusia (SDM) menjadi penilai dalam penentuan nilai Required Competency Level (RCL) seluruh arsiparis di Kemensetneg.

Teknik pengolahan data dilakukan dengan lebih dahulu menguji validitas terhadap instrumen kuesioner yang digunakan. Instrumen penelitian dapat dikatakan valid apabila $r$ hitung lebih besar dari $r$ tabel ( $r$ hitung $>r$ tabel) (Sugiyono, 2010:190). Setiap jenjang jabatan arsiparis memiliki intrumen yang berbeda dan apabila terdapat instrumen yang tidak valid maka akan dihilangkan dari instrumen penelitian.

Selanjutnya pada instrumen penelitian dilakukan pengujian reliabilitas, dengan tujuan mengetahui

Tabel 3

Hasil Analisis Uji Validitas dan Reliabilitas Instrumen

\begin{tabular}{|l|c|c|}
\hline \multicolumn{1}{|c|}{ Jenjang Jabatan } & $\begin{array}{c}\text { Kisaran Nilai Koefisien } \\
\text { Validitas }\end{array}$ & $\begin{array}{c}\text { Nilai Koefisien } \\
\text { Reliabilitas }\end{array}$ \\
\hline Arsiparis Terampil & $0.653-0.913$ & 0.985 \\
\hline Arsiparis Mahir & $0.842-0.959$ & 0.994 \\
\hline Arsiparis Penyelia & $0.840-0.991$ & 0.995 \\
\hline Arsiapris Ahli Pertama & $0.647-0.923$ & 0.986 \\
\hline Arsiparis Ahli Muda & $0.653-0.913$ & 0.991 \\
\hline
\end{tabular}

Sumber: Data Primer, 2021. 
konsistensi hasil pengukuran instrumen. Pengujian reliabilitas pada penelitian ini menggunakan teknik Alpha Cronbach dengan taraf nyata 5\%. Menurut Ghozali (2011:48) jika suatu variabel memberikan nilai Alpha Cronbach > 0,6 maka item tersebut dinyatakan andal.

Dari masing-masing instrumen berdasarkan jenjang jabatan maka terdapat rincian hasil analisis uji validitas dan keandalan seperti pada Tabel 3. Dari rincian pada Tabel 3 maka dapat dinyatakan instrumen penelitian valid dan andal. Hal ini menunjukkan bahwa instrumen dapat digunakan untuk mengukur dan mengungkap data yang diteliti.

Selanjutnya, analisis kesenjangan kompetensi terhadap data yang didapat yang dilakukan dengan cara Pertama, mengidentifikasi kompetensi yang dibutuhkan melalui studi pustaka atau pendapat para pakar. Dalam penelitian ini, kompetensi yang dibutuhkan arsiparis diperoleh dari standar kompetensi dan tugas jabatan arsiparis. Kedua, menyusun kuesioner penelitian yang digunakan untuk melakukan penilaian terhadap level kompetensi yang diperlukan (RCL), level kompetensi saat ini (CCL) dan tingkat kepentingan kompetensi terhadap pekerjaan berdasarkan jenjang jabatan arsiparis.

Ketiga, menilai RCL, CCL, dan tingkat kepentingan kompetensi arsiparis. Penilaian terhadap RCL dan tingkat kepentingan kompetensi dilakukan pejabat berwenang unit pembina arsiparis Kemensetneg. Penilaian rata-rata CCL dilakukan berdasarkan self assessment arsiparis dan atasannya. Penilaian CCL, RCL dan tingkat kepentingan kompetensi menggunakan skala 1 (terkecil) sampai dengan 5 (terbesar).

Ke e mpat, menganalis is kesenjangan kemampuan kerja dengan membandingkan nilai RCL dan CCL. Perbedaan atau selisih nilai RCL dan CCL dinyatakan sebagai kesenjangan kemampuan kerja arsiparis. Rata-rata nilai RCL dan CCL diolah dengan menggunakan rumus:

$\mathrm{PPK}=\mathrm{GAP} \times \mathrm{TK}$

Keterangan

PPK $=$ Skor Prioritas Pengembangan

Kompetensi

$\mathrm{GAP}=$ Skor Kesenjangan

$\mathrm{TK}=$ Skor Tingkat Kepentingan

Kompetensi

Maka dapat dipetakan prioritas pengembangan kompetensi berdasarkan skor PPK dari skor terbesar ke skor terkecil.

Keenam, memetakan prioritas kompetensi ke dalam kelompok sebaran data untuk masing-masing jenjang jabatan dengan menggunakan tabel distribusi frekuensi dengan kelas pertama kriteria "Prioritas Sangat Rendah", kelas kedua 
dengan kriteria "Prioritas Rendah", kelas ketiga dengan kriteria "Prioritas Sedang", kelas keempat dengan kriteria "Prioritas Tinggi”, dan kelas kelima dengan kriteria "Prioritas Sangat Tinggi”.

Hasil pembagian kelompok prioritas dengan tabel distribusi frekuensi tersebut, menunjukkan pembagian kelompok untuk masing-masing tingkat prioritas kompetensi yang diperoleh dari hasil penelitian.

\section{Kerangka Pemikiran}

Untuk menjaga keutuhan arsip tentunya dipengaruhi berbagai macam faktor. Salah satu faktor vital yang mendorong hal tersebut adalah sumber daya manusia, yang dalam hal ini adalah arsiparis. Arsiparis sebagai SDM kearsipan tentunya perlu dikelola dengan baik. Bentuk pengelolaan SDM sering disebut dengan Manajemen Sumber Daya Manusia (MSDM). MSDM bertujuan untuk memberikan pembinaan bagi SDM agar dapat memberikan kontribusi secara efektif dan efisien dalam pencapaian sasaran organisasi. Sutrisno (2009:8) mengemukakan tujuan utama dari MSDM adalah memperbaiki tingkat produktivitas, memperbaiki kualitas kehidupan kerja dan meyakinkan organisasi telah memenuhi aspek-aspek legal.

Pelatihan merupakan salah satu bentuk perwujudan dari MSDM. Pelatihan dapat dideskripsikan sebagai suatu upaya terencana organisasi untuk memberi kemudahan sistem pembelajaran bagi para pegawai mengenai kompetensi yang berhubungan dengan pelaksanaan tugas dan pekerjaan (Soetadikaria, 2017:5). Dalam melaksanakan pelatihan tentunya terdapat beberapa tahapan yang perlu dilakukan sehingga pelatihan yang dimaksudkan sesuai dengan kebutuhan dan tepat sasaran. Goldstein dan Ford (2002:86) menyatakan bahwa implementasi pelatihan terdiri atas tiga tahap: tahap penilaian, tahap pelatihan, dan tahap evaluasi.

Tahap penilaian terdiri dari kebutuhan organisasi, tugas, dan individu. Proses penilaian tersebut sering juga disebut sebagai analisis kebutuhan yang di antaranya terdiri atas analisis organisasi, individu, dan tugas. Analisis organisasi mengedepankan konteks di mana pelatihan akan dilaksanakan meliputi penentuan kelayakan pelatihan, penentuan strategi bisnis berdasarkan sumber daya pelatihan yang tersedia, dan dukungan para manajer serta rekan kerja terhadap aktivitas pelatihan. Analisis individu digunakan untuk mengidentifikasi individu yang memerlukan pelatihan, meliputi penentuan sebab dari ketidakcukupan hasil kinerja, apakah berasal dari pengetahuan yang kurang, masalah keterampilan, kemampuan (masalah pelatihan), berasal dari masalah motivasi 
kerja, identifikasi kebutuhan individu, atau penentuan kesiapan individu untuk mengikuti pelatihan. Analisis tugas mencakup identifikasi tugas, pengetahuan, dan keterampilan serta perilaku yang perlu ditekankan pada pelatihan bagi pegawai agar tugasnya dapat terselesaikan dengan baik (Noe et al., 2010:277).

Salah satu alternatif cara menganalisis kebutuhan pelatihan adalah dengan menggunakan pendekatan analisis kesenjangan. Untuk menggambarkan kesenjangan, menurut Palan (2007:88) diperlukan penentuan level kompetensi yang dibutuhkan (Required Competency Level/RCL) dan level kompetensi saat ini (Current Competency Level/CCL). RCL adalah tingkat kemahiran minimum yang diharapkan dari seseorang pada kompetensi yang dituntut oleh pekerjaan sedangkan CCL adalah tingkat kemahiran yang dimiliki seseorang saat ini pada kompetensi tertentu.

Dalam praktiknya, analisis kesenjangan dapat dikatakan pula dengan istilah kesenjangan kompetensi (competency gap). Palan (2007:119) mendeskripsikan kesenjangan kompetensi pegawai sebagai suatu perbedaan yang muncul antara level kompetensi yang dibutuhkan (RCL) pada suatu posisi tertentu dengan level kompetensi yang ada saat ini (CCL). Kesenjangan ini dapat diketahui dengan

perhitungan menggunakan rumus berikut:

$\mathrm{GAP}=\mathrm{RCL}-\mathrm{CCL}$

Dari kesenjangan tersebut nantinya akan menentukan program pengembangan yang diperlukan. Baik bentuk pelatihan maupun bentuk pengembangan lainnya. Berdasarkan beberapa pendapat yang telah dijabarkan di atas, maka dapat disimpulkan bahwa analisis kebutuhan pelatihan mampu menghasilkan rumusan perancangan program pelatihan.

\section{PEMBAHASAN \\ Kebutuhan Pelatihan}

Dari hasil penelitian, ditemukan beberapa temuan. Pertama, CCL Arsiparis Terampil untuk Kompetensi Manajerial berkisar antara 3,74 - 3,96 atau dapat dikategorikan menengah jika mengacu pada level kompetensi seperti yang disebutkan dalam Peraturan Kementerian Pendayagunaan Aparatur Negara dan Reformasi Birokrasi Nomor 38 Tahun 2017 sedangkan RCL-nya berkisar antara 4,00 - 5,00 atau kriteria mumpuni dan ahli, dengan kesenjangan kisaran antara 0,22 - 1,08. Current Competency Level (CCL) Arsiparis Terampil untuk Kompetensi Sosial Kultural bernilai 4,04 atau dapat dikategorikan mumpuni sedangkan RCL-nya bernilai 4,33 atau dapat dikategorikan mumpuni, dengan 
Khazanah: Jurnal Pengembangan Kearsipan, 2021, Vol. 14 (2)

Tabel 4

Kesenjangan Kompetensi Jenjang Arsiparis Terampil

\begin{tabular}{|c|c|c|c|c|}
\hline Jenis Kompetensi & Subkompetensi & CCL & $\mathrm{RCL}$ & Kesenjangan \\
\hline \multirow{8}{*}{ Manajerial } & Integritas & 3,92 & 5 & 1,08 \\
\hline & Kerja Sama & 3,92 & 5 & 1,08 \\
\hline & Komunikasi & 3,82 & 4,33 & 0,51 \\
\hline & Orientasi pada Hasil & 3,96 & 5 & 1,04 \\
\hline & Pelayanan Publik & 3,87 & 4,83 & 0,96 \\
\hline & Pengembangan Diri dan Orang Lain & 3,71 & 4 & 0,29 \\
\hline & Mengelola Perubahan & 3,78 & 4 & 0,22 \\
\hline & Pengambilan Keputusan & 3,74 & 4,17 & 0,43 \\
\hline Sosial Kultural & Perekat Bangsa & 4,04 & 4,33 & 0,3 \\
\hline \multirow{3}{*}{ Teknis } & Pengelolaan Arsip Dinamis & 3,98 & 4,9 & 0,92 \\
\hline & Pembinaan Kearsipan & 3,16 & 4 & 0,84 \\
\hline & $\begin{array}{l}\text { Pengolahan Arsip Menjadi } \\
\text { Informasi }\end{array}$ & 3,68 & 4,5 & 0,82 \\
\hline
\end{tabular}

Sumber: Data Primer, 2021.

kesenjangan bernilai 0,30. Current Competency Level (CCL) Arsiparis Terampil untuk Kompetensi Teknis berkisar antara 3,16 - 3,98 atau dapat dikategorikan menengah sedangkan RCLnya berkisar antara 4,00-4,90 atau dapat dikategorikan mumpuni, dengan kesenjangan kisaran antara 0,82-0,92. Adapun rinciannya sebagaimana tertuang dalam Tabel 4. Kedua, CCL Arsiparis Mahir untuk Kompetensi Manajerial berkisar antara 3,57 - 3,89 atau dapat dikategorikan menengah sedangkan RCLnya berkisar antara 4,00 - 5,00 atau dapat dikategorikan mumpuni dan ahli, dengan kesenjangan kisaran antara 0,35 - 1,43. Current Competency Level (CCL)
Arsiparis Mahir untuk Kompetensi Sosial Kultural bernilai 3,98 atau dapat dikategorikan menengah sedangkan RCLnya bernilai 4,33 atau dapat dikategorikan mumpuni, dengan kesenjangan bernilai 0,35. Current Competency Level (CCL) Arsiparis Mahir untuk Kompetensi Teknis berkisar antara 3,05 - 3,74 atau dapat dikategorikan menengah sedangkan RCLnya berkisar antara 4,00-5,00 atau dapat dikategorikan mumpuni, dengan kesenjangan kisaran antara 0,95 - 1,52. Adapun rinciannya sebagaimana tertuang dalam Tabel 5. Ketiga, CCL Arsiparis Penyelia untuk Kompetensi Manajerial berkisar antara 3,27 - 3,57 atau dapat dikategorikan menengah sedangkan RCL- 
Tabel 5

Kesenjangan Kompetensi Jenjang Arsiparis Mahir

\begin{tabular}{|l|l|c|c|c|}
\hline Jenis Kompetensi & Subkompetensi & CCL & \multicolumn{1}{l}{ RCL } & Kesenjangan \\
\hline & Integritas & 3,89 & 5 & 1,11 \\
\cline { 2 - 4 } & Kerja Sama & 3,88 & 5 & 1,13 \\
\cline { 2 - 4 } Manajerial & Komunikasi & 3,73 & 4,33 & 0,6 \\
\cline { 2 - 5 } & Orientasi pada Hasil & 3,57 & 5 & 1,43 \\
\cline { 2 - 5 } & Pelayanan Publik & 3,56 & 4,83 & 1,27 \\
\cline { 2 - 5 } & Pengembangan Diri dan Orang Lain & 3,63 & 4 & 0,38 \\
\cline { 2 - 5 } & Mengelola Perubahan & 3,65 & 4 & 0,35 \\
\hline \multirow{2}{*}{ Sosial Kultural } & Pengambilan Keputusan & 3,6 & 4,17 & 0,56 \\
\hline \multirow{3}{*}{ Teknis } & Perekat Bangsa & 3,98 & 4,33 & 0,35 \\
\hline & Pengelolaan Arsip Dinamis & 3,74 & 5 & 1,26 \\
\cline { 2 - 5 } & Pengelolaan Arsip Statis & 3,48 & 5 & 1,52 \\
\cline { 2 - 5 } & Pembinaan Kearsipan & 3,05 & 4 & 0,95 \\
\cline { 2 - 5 } & Pengolahan Arsip Menjadi Informasi & 3,48 & 4,5 & 1,02 \\
\hline
\end{tabular}

Sumber: Data Primer, 2021.

nya bernilai 5,00 atau dapat dikategorikan ahli, dengan kesenjangan kisaran antara 1,47 - 1,73. Current Competency Level (CCL) Arsiparis Penyelia untuk Kompetensi Sosial Kultural bernilai 3,47 atau dapat dikategorikan menengah sedangkan RCL-nya bernilai 4,50 atau dapat dikategorikan mumpuni dengan kesenjangan bernilai 1,03. Current Competency Level (CCL) Arsiparis Penyelia untuk Kompetensi Teknis berkisar antara 3,53 - 4,10 atau dapat dikategorikan menengah dan mumpuni sedangkan RCL-nya bernilai 5,00 atau dapat dikategorikan ahli, dengan kesenjangan kisaran antara 0,90 - 1,47. Adapun rinciannya sebagaimana tertuang dalam Tabel 6.
Keempat, CCL Arsiparis Ahli Pertama untuk Kompetensi Manajerial berkisar antara 4,17- 4,83 atau dapat dikategorikan mumpuni sedangkan RCLnya bernilai 5,00 atau dapat dikategorikan ahli, dengan kesenjangan kisaran antara 0,17 - 0,83. Current Competency Level (CCL) Arsiparis Ahli Pertama untuk Kompetensi Sosial Kultural bernilai 4,00 atau dapat dikategorikan mumpuni sedangkan RCL-nya bernilai 4,50 atau dapat dikategorikan mumpuni, dengan kesenjangan bernilai 0,50. Current Competency Level (CCL) Arsiparis Ahli Pertama untuk Kompetensi Teknis berkisar antara 4,80 - 4,88 atau dapat dikategorikan mumpuni sedangkan RCLnya berkisar antara 4,40-5,00 atau dapat 
Tabel 6

Kesenjangan Kompetensi Jenjang Arsiparis Penyelia

\begin{tabular}{|l|l|c|c|c|}
\hline Jenis Kompetensi & \multicolumn{1}{|c|}{ Subkompetensi } & CCL & RCL & Kesenjangan \\
\hline & Integritas & 3,57 & 5 & 1,43 \\
\cline { 2 - 5 } & Kerja Sama & 3,5 & 5 & 1,5 \\
\cline { 2 - 5 } & Komunikasi & 3,43 & 5 & 1,57 \\
\cline { 2 - 5 } Manajerial & Orientasi pada Hasil & 3,4 & 5 & 1,6 \\
\cline { 2 - 5 } & Pelayanan Publik & 3,57 & 5 & 1,43 \\
\cline { 2 - 5 } & Pengembangan Diri dan Orang Lain & 3,27 & 5 & 1,73 \\
\cline { 2 - 5 } & Mengelola Perubahan & 3,53 & 5 & 1,47 \\
\cline { 2 - 5 } & Pengambilan Keputusan & 3,53 & 5 & 1,47 \\
\hline Sosial Kultural & Perekat Bangsa & 3,47 & 4,5 & 1,03 \\
\hline \multirow{5}{*}{ Teknis } & Pengelolaan Arsip Dinamis & 4,05 & 5 & 0,95 \\
\cline { 2 - 5 } & Pengelolaan Arsip Statis & 4,1 & 5 & 0,9 \\
\cline { 2 - 5 } & Pembinaan Kearsipan & 3,53 & 5 & 1,47 \\
\cline { 2 - 5 } & Pengolahan Arsip Menjadi Informasi & 4,06 & 5 & 0,94 \\
\hline
\end{tabular}

Sumber: Data Primer, 2021.

dikategorikan mumpuni dan ahli, dengan kesenjangan kisaran antara $-0,40-0,14$. Adapun rinciannya sebagaimana tertuang dalam Tabel 7.

Kelima, CCL Arsiparis Ahli Muda untuk Kompetensi Manajerial berkisar antara $3,80-4,00$ atau dapat dikategorikan menengah dan mumpuni sedangkan RCL-nya bernilai 5,00 atau dapat dikategorikan ahli, dengan kesenjangan kisaran antara 1,00 - 1,20. Current Competency Level (CCL) Arsiparis Ahli Muda untuk Kompetensi Sosial Kultural bernilai 4,07 atau dapat dikategorikan mumpuni sedangkan RCLnya bernilai 4,50 atau dapat dikategorikan mumpuni, dengan kesenjangan bernilai 0,43. Current Competency Level (CCL)
Arsiparis Terampil untuk Kompetensi Teknis berkisar antara 3,50 - 4,03 atau dapat dikategorikan menengah mumpuni sedangkan RCL-nya bernilai 5,00 atau dapat dikategorikan ahli, dengan kesenjangan kisaran antara 0,98 - 1,50. Adapun rinciannya sebagaimana tertuang dalam Tabel 8.

Dari data-data tersebut dapat ditemukan bahwa terdapat kesenjangan kompetensi di masing-masing jenjang arsiparis. Kesenjangan kompetensi tersebut pun menyebar di setiap jenis kompetensi baik itu kompetensi manajerial, sosial kultural maupun teknis. Kesenjangan kompetensi tersebut berkisar antara 0,13 sampai dengan 1,73 yang artinya masih terdapat kesenjangan 
Khazanah: Jurnal Pengembangan Kearsipan, 2021, Vol. 14 (2)

Tabel 7

Kesenjangan Kompetensi Jenjang Arsiparis Ahli Pertama

\begin{tabular}{|l|l|c|c|c|}
\hline Jenis Kompetensi & Subkompetensi & CCL & RCL & Kesenjangan \\
\hline \multirow{5}{*}{ Manajerial } & Integritas & 4,33 & 5 & 0,67 \\
\cline { 2 - 5 } & Kerja Sama & 4,5 & 5 & 0,5 \\
\cline { 2 - 5 } & Komunikasi & 4,33 & 5 & 0,67 \\
\cline { 2 - 5 } & Orientasi pada Hasil & 4,83 & 5 & 0,17 \\
\cline { 2 - 5 } & Pelayanan Publik & 4,17 & 5 & 0,83 \\
\cline { 2 - 5 } & Pengembangan Diri dan Orang Lain & 4,5 & 5 & 0,5 \\
\cline { 2 - 5 } & Mengelola Perubahan & 4,5 & 5 & 0,5 \\
\hline \multirow{5}{*}{ Sosial Kultural } & Pengambilan Keputusan & 4,5 & 5 & 0,5 \\
\hline \multirow{5}{*}{ Teknis } & Perekat Bangsa & 4 & 4,5 & 0,5 \\
\cline { 2 - 5 } & Pengelolaan Arsip Dinamis & 4,86 & 5 & 0,14 \\
\cline { 2 - 5 } & Pembinaan Kearsipan & 4,8 & 4,4 & $-0,4$ \\
\cline { 2 - 5 } & $\begin{array}{l}\text { Pengolahan Arsip Menjadi } \\
\text { Informasi }\end{array}$ & 4,88 & 5 & 0,13 \\
\hline
\end{tabular}

Sumber: Data Primer, 2021.

yang signifikan yang memerlukan penanganan yang memadai.

Setelah dipetakan CCL, RCL, dan kesenjangan setiap jenjang arsiparis maka langkah selanjutnya adalah menentukan prioritas kompetensi yang perlu diberikan pelatihan. Hal itu dilakukan dengan mengkalikan nilai kesenjangan dengan nilai tingkat kepentingan maka terpetakanlah tingkat prioritas kebutuhan masing-masing kompetensi. Selanjutnya, dibagi ke dalam kelompok sebaran data untuk masing-masing jenjang jabatan dengan menggunakan tabel distribusi frekuensi. Untuk membatasi keluasan pembahasan prioritas kompetensi yang perlu diberikan pelatihan, maka ditentukan kompetensi yang menjadi prioritas adalah mereka yang berasal dari kelompok skala prioritas tertinggi di masing-masing jenjang jabatan arsiparis.

Berdasarkan hasil pengolahan dengan tabel distribusi frekuensi maka ditemukan temuan yang menggambarkan prioritas kompetensi untuk jenjang Arsiparis Terampil seperti tercermin pada Tabel 9.

Adapun untuk Arsiparis Mahir, hasil pengolahan dengan tabel distribusi frekuensinya, maka ditemukan pula gambaran prioritas kompetensi untuk jenjang Arsiparis Mahir seperti tercermin pada Tabel 10.

Berdasarkan hasil pengolahan 
Khazanah: Jurnal Pengembangan Kearsipan, 2021, Vol. 14 (2)

Tabel 8

Kesenjangan Kompetensi Jenjang Arsiparis Ahli Muda

\begin{tabular}{|l|l|c|c|c|}
\hline Jenis Kompetensi & Subkompetensi & CCL & RCL & Kesenjangan \\
\hline \multirow{5}{*}{ Manajerial } & Integritas & 3,87 & 5 & 1,13 \\
\cline { 2 - 5 } & Kerja Sama & 4 & 5 & 1 \\
\cline { 2 - 5 } & Komunikasi & 3,8 & 5 & 1,2 \\
\cline { 2 - 5 } & Orientasi pada Hasil & 3,83 & 5 & 1,17 \\
\cline { 2 - 5 } & Pelayanan Publik & 3,8 & 5 & 1,2 \\
\cline { 2 - 5 } & Pengembangan Diri dan Orang Lain & 3,87 & 5 & 1,13 \\
\cline { 2 - 5 } Sosial Kultural & Mengelola Perubahan & 3,87 & 5 & 1,13 \\
\cline { 2 - 5 } & Pengambilan Keputusan & 3,87 & 5 & 1,13 \\
\hline \multirow{5}{*}{ Peknis } & Perekat Bangsa & 4,07 & 4,5 & 0,43 \\
\cline { 2 - 5 } & Pengelolaan Arsip Dinamis & 4,03 & 5 & 0,98 \\
\cline { 2 - 5 } & Pengelolaan Arsip Statis & 3,5 & 5 & 1,5 \\
\cline { 2 - 5 } & Pembinaan Kearsipan & 3,58 & 5 & 1,42 \\
\cline { 2 - 5 } & Pengolahan Arsip Menjadi & 3,8 & 5 & 1,2 \\
\hline & Informasi & & & \\
\hline
\end{tabular}

Sumber: Data Primer, 2021.

dengan tabel distribusi frekuensi, maka ditemukan pula gambaran prioritas kompetensi untuk jenjang Arsiparis Penyelia seperti yang tercermin pada Tabel 11.

Berdasarkan hasil pengolahan dengan tabel distribusi frekuensi, maka ditemukan pula temuan yang menggambarkan prioritas kompetensi untuk jenjang Arsiparis Ahli Pertama seperti yang tercermin pada Tabel 12.

Berdasarkan hasil pengolahan dengan tabel distribusi frekuensi, maka ditemukan pula temuan yang menggambarkan prioritas kompetensi untuk jenjang Arsiparis Ahli Muda seperti yang tercermin pada Tabel 13.

Berdasarkan pembatasan lingkup prioritas kompetensi yang telah disebutkan sebelumnya maka pembahasan selanjutnya akan difokuskan pada kompetensi yang termasuk dalam kriteria prioritas sangat tinggi sebagaimana yang tertuang pada Tabel 14 .

Jika mengacu pada Tabel 14 maka terdapat temuan yang menarik yaitu bahwa tidak terdapat satu pun kompetensi Sosial Kultural yang termasuk ke dalam kompetensi yang berkriteria prioritas sangat tinggi. Kompetensi Sosial Kultural hanya memiliki satu subkompetesi yaitu Perekat Bangsa. Kompetensi Perekat Bangsa hampir di semua jenjang jabatan arsiparis termasuk kompetensi berkriteria prioritas sangat rendah untuk mendapatkan pelatihan. Dari temuan ini, 
Khazanah: Jurnal Pengembangan Kearsipan, 2021, Vol. 14 (2)

Tabel 9

Prioritas Kompetensi Jenjang Arsiparis Terampil

\begin{tabular}{|c|c|c|c|c|c|}
\hline Jenis Kompetensi & Subkompetensi & Kesenjangan & Kepentingan & Prioritas & Kriteria \\
\hline \multirow{8}{*}{ Manajerial } & Integritas & 1,08 & 4,83 & 5,21 & Prioritas Sangat Tinggi \\
\hline & Kerja Sama & 1,08 & 4,17 & 4,5 & Prioritas Sangat Tinggi \\
\hline & Komunikasi & 0,51 & 4,33 & 2,2 & Prioritas Rendah \\
\hline & Orientasi pada Hasil & 1,04 & 5 & 5,18 & Prioritas Sangat Tinggi \\
\hline & Pelayanan Publik & 0,96 & 4,83 & 4,66 & Prioritas Sangat Tinggi \\
\hline & $\begin{array}{l}\text { Pengembangan Diri dan } \\
\text { Orang Lain }\end{array}$ & 0,29 & 4 & 1,16 & Prioritas Sangat Rendah \\
\hline & Mengelola Perubahan & 0,22 & 4 & 0,88 & Prioritas Sangat Rendah \\
\hline & Pengambilan Keputusan & 0,43 & 4,17 & 1,79 & Prioritas Rendah \\
\hline Sosial Kultural & Perekat Bangsa & 0,3 & 4,33 & 1,29 & Prioritas Sangat Rendah \\
\hline \multirow{3}{*}{ Teknis } & $\begin{array}{l}\text { Pengelolaan Arsip } \\
\text { Dinamis }\end{array}$ & 0,92 & 4,9 & 4,51 & Prioritas Sangat Tinggi \\
\hline & Pembinaan Kearsipan & 0,84 & 4 & 3,37 & Prioritas Sedang \\
\hline & $\begin{array}{l}\text { Pengolahan Arsip } \\
\text { Menjadi Informasi }\end{array}$ & 0,82 & 4,5 & 3,67 & Prioritas Tinggi \\
\hline
\end{tabular}

Sumber: Data Primer, 2021.

Tabel 10

Prioritas Kompetensi Jenjang Arsiparis Mahir

\begin{tabular}{|c|c|c|c|c|c|}
\hline Jenis Kompetensi & Subkompetensi & Kesenjangan & Kepentingan & Prioritas & Kriteria \\
\hline \multirow{8}{*}{ Manajerial } & Integritas & 1,11 & 4,83 & 5,39 & Prioritas Tinggi \\
\hline & Kerja Sama & 1,13 & 4,17 & 4,69 & Prioritas Sedang \\
\hline & Komunikasi & 0,6 & 4,33 & 2,62 & $\begin{array}{c}\text { Prioritas Sangat } \\
\text { Rendah }\end{array}$ \\
\hline & Orientasi pada Hasil & 1,43 & 5 & 7,14 & $\begin{array}{c}\text { Prioritas Sangat } \\
\text { Tinggi } \\
\end{array}$ \\
\hline & Pelayanan Publik & 1,27 & 4,83 & 6,14 & Prioritas Tinggi \\
\hline & $\begin{array}{l}\text { Pengembangan Diri } \\
\text { dan Orang Lain }\end{array}$ & 0,38 & 4 & 1,5 & $\begin{array}{c}\text { Prioritas Sangat } \\
\text { Rendah }\end{array}$ \\
\hline & Mengelola Perubahan & 0,35 & 4 & 1,42 & $\begin{array}{c}\text { Prioritas Sangat } \\
\text { Rendah } \\
\end{array}$ \\
\hline & \begin{tabular}{|l|} 
Pengambilan \\
Keputusan
\end{tabular} & 0,56 & 4,17 & 2,34 & $\begin{array}{c}\text { Prioritas Sangat } \\
\text { Rendah } \\
\end{array}$ \\
\hline Sosial Kultural & Perekat Bangsa & 0,35 & 4,33 & 1,53 & $\begin{array}{l}\text { Prioritas Sangat } \\
\text { Rendah } \\
\end{array}$ \\
\hline \multirow{4}{*}{ Teknis } & $\begin{array}{l}\text { Pengelolaan Arsip } \\
\text { Dinamis }\end{array}$ & 1,26 & 5 & 6,28 & Prioritas Tinggi \\
\hline & \begin{tabular}{|l} 
Pengelolaan Arsip \\
Statis
\end{tabular} & 1,52 & 5 & 7,58 & $\begin{array}{c}\text { Prioritas Sangat } \\
\text { Tinggi } \\
\end{array}$ \\
\hline & Pembinaan Kearsipan & 0,95 & 4 & 3,81 & Prioritas Rendah \\
\hline & $\begin{array}{l}\text { Pengolahan Arsip } \\
\text { Menjadi Informasi }\end{array}$ & 1,02 & 4,5 & 4,57 & Prioritas Sedang \\
\hline
\end{tabular}

Sumber: Data Primer, 2021. 
Tabel 11

Prioritas Kompetensi Jenjang Arsiparis Penyelia

\begin{tabular}{|c|c|c|c|c|c|}
\hline Jenis Kompetensi & Subkompetensi & Kesenjangan & Kepentingan & Prioritas & Kriteria \\
\hline \multirow{8}{*}{ Manajerial } & Integritas & 1,43 & 5 & 7,17 & Prioritas Tinggi \\
\hline & Kerja Sama & 1,5 & 5 & 7,5 & $\begin{array}{c}\text { Prioritas Sangat } \\
\text { Tinggi } \\
\end{array}$ \\
\hline & Komunikasi & 1,57 & 5 & 7,83 & $\begin{array}{c}\text { Prioritas Sangat } \\
\text { Tinggi }\end{array}$ \\
\hline & $\begin{array}{l}\text { Orientasi pada } \\
\text { Hasil }\end{array}$ & 1,6 & 5 & 8 & $\begin{array}{c}\text { Prioritas Sangat } \\
\text { Tinggi }\end{array}$ \\
\hline & Pelayanan Publik & 1,43 & 5 & 7,17 & Prioritas Tinggi \\
\hline & $\begin{array}{l}\text { Pengembangan } \\
\text { Diri dan Orang } \\
\text { Lain }\end{array}$ & 1,73 & 4,5 & 7,8 & $\begin{array}{c}\text { Prioritas Sangat } \\
\text { Tinggi }\end{array}$ \\
\hline & $\begin{array}{l}\text { Mengelola } \\
\text { Perubahan }\end{array}$ & 1,47 & 4,5 & 6,6 & Prioritas Tinggi \\
\hline & $\begin{array}{l}\text { Pengambilan } \\
\text { Keputusan } \\
\end{array}$ & 1,47 & 4,5 & 6,6 & Prioritas Tinggi \\
\hline Sosial Kultural & Perekat Bangsa & 1,03 & 4,5 & 4,65 & $\begin{array}{c}\text { Prioritas Sangat } \\
\text { Rendah } \\
\end{array}$ \\
\hline \multirow{4}{*}{ Teknis } & $\begin{array}{l}\text { Pengelolaan Arsip } \\
\text { Dinamis }\end{array}$ & 0,95 & 5 & 4,75 & $\begin{array}{c}\text { Prioritas Sangat } \\
\text { Rendah }\end{array}$ \\
\hline & $\begin{array}{l}\text { Pengelolaan Arsip } \\
\text { Statis }\end{array}$ & 0,9 & 5 & 4,5 & $\begin{array}{c}\text { Prioritas Sangat } \\
\text { Rendah }\end{array}$ \\
\hline & \begin{tabular}{l|} 
Pembinaan \\
Kearsipan
\end{tabular} & 1,47 & 5 & 7,33 & $\begin{array}{c}\text { Prioritas Sangat } \\
\text { Tinggi } \\
\end{array}$ \\
\hline & $\begin{array}{l}\text { Pengolahan Arsip } \\
\text { Menjadi Informasi }\end{array}$ & 0,94 & 5 & 4,7 & $\begin{array}{c}\text { Prioritas Sangat } \\
\text { Rendah }\end{array}$ \\
\hline
\end{tabular}

Sumber: Data Primer, 2021.

Tabel 12

Prioritas Kompetensi Jenjang Arsiparis Ahli Pertama

\begin{tabular}{|c|c|c|c|c|c|}
\hline Jenis Kompetensi & Subkompetensi & Kesenjangan & Kepentingan & Prioritas & Kriteria \\
\hline \multirow{8}{*}{ Manajerial } & Integritas & 0,67 & 5 & 3,33 & $\begin{array}{c}\text { Prioritas Sangat } \\
\text { Tinggi }\end{array}$ \\
\hline & Kerja Sama & 0,5 & 5 & 2,5 & Prioritas Tinggi \\
\hline & Komunikasi & 0,67 & 5 & 3,33 & $\begin{array}{c}\text { Prioritas Sangat } \\
\text { Tinggi } \\
\end{array}$ \\
\hline & $\begin{array}{l}\text { Orientasi pada } \\
\text { Hasil }\end{array}$ & 0,17 & 5 & 0,83 & Prioritas Sedang \\
\hline & Pelayanan Publik & 0,83 & 5 & 4,17 & $\begin{array}{c}\text { Prioritas Sangat } \\
\text { Tinggi } \\
\end{array}$ \\
\hline & $\begin{array}{l}\text { Pengembangan } \\
\text { Diri dan Orang } \\
\text { Lain }\end{array}$ & 0,5 & 4,5 & 2,25 & Prioritas Tinggi \\
\hline & $\begin{array}{l}\text { Mengelola } \\
\text { Perubahan }\end{array}$ & 0,5 & 4,5 & 2,25 & Prioritas Tinggi \\
\hline & $\begin{array}{l}\text { Pengambilan } \\
\text { Keputusan }\end{array}$ & 0,5 & 4,5 & 2,25 & Prioritas Tinggi \\
\hline Sosial Kultural & Perekat Bangsa & 0,5 & 4,5 & 2,25 & Prioritas Tinggi \\
\hline \multirow{3}{*}{ Teknis } & $\begin{array}{l}\begin{array}{l}\text { Pengelolaan Arsip } \\
\text { Dinamis }\end{array} \\
\end{array}$ & 0,14 & 5 & 0,71 & Prioritas Sedang \\
\hline & $\begin{array}{l}\text { Pembinaan } \\
\text { Kearsipan }\end{array}$ & $-0,4$ & 4,4 & $-1,76$ & $\begin{array}{c}\text { Prioritas Sangat } \\
\text { Rendah }\end{array}$ \\
\hline & $\begin{array}{l}\text { Pengolahan Arsip } \\
\text { Menjadi Informasi }\end{array}$ & 0,13 & 5 & 0,63 & Prioritas Sedang \\
\hline
\end{tabular}

Sumber: Data Primer, 2021. 
Khazanah: Jurnal Pengembangan Kearsipan, 2021, Vol. 14 (2)

Tabel 13

Prioritas Kompetensi Jenjang Arsiparis Ahli Muda

\begin{tabular}{|c|c|c|c|c|c|}
\hline Jenis Kompetensi & Subkompetensi & Kesenjangan & Kepentingan & Prioritas & Kriteria \\
\hline \multirow{8}{*}{ Manajerial } & Integritas & 1,13 & 5 & 5,67 & Prioritas Tinggi \\
\hline & Kerja Sama & 1 & 5 & 5 & Prioritas Sedang \\
\hline & Komunikasi & 1,2 & 5 & 6 & Prioritas Tinggi \\
\hline & $\begin{array}{l}\text { Orientasi pada } \\
\text { Hasil }\end{array}$ & 1,17 & 5 & 5,83 & Prioritas Tinggi \\
\hline & \begin{tabular}{|l} 
Pelayanan \\
Publik \\
\end{tabular} & 1,2 & 5 & 6 & Prioritas Tinggi \\
\hline & $\begin{array}{l}\text { Pengembangan } \\
\text { Diri dan Orang } \\
\text { Lain } \\
\end{array}$ & 1,13 & 4,5 & 5,1 & Prioritas Sedang \\
\hline & $\begin{array}{l}\text { Mengelola } \\
\text { Perubahan }\end{array}$ & 1,13 & 4,5 & 5,1 & Prioritas Sedang \\
\hline & $\begin{array}{l}\text { Pengambilan } \\
\text { Keputusan }\end{array}$ & 1,13 & 4,5 & 5,1 & Prioritas Sedang \\
\hline Sosial Kultural & Perekat Bangsa & 0,43 & 4,5 & 1,95 & $\begin{array}{c}\text { Prioritas Sangat } \\
\text { Rendah }\end{array}$ \\
\hline \multirow{4}{*}{ Teknis } & $\begin{array}{l}\text { Pengelolaan } \\
\text { Arsip Dinamis }\end{array}$ & 0,98 & 4,88 & 4,75 & Prioritas Sedang \\
\hline & $\begin{array}{l}\text { Pengelolaan } \\
\text { Arsip Statis } \\
\end{array}$ & 1,5 & 5 & 7,5 & $\begin{array}{c}\text { Prioritas Sangat } \\
\text { Tinggi }\end{array}$ \\
\hline & $\begin{array}{l}\text { Pembinaan } \\
\text { Kearsipan }\end{array}$ & 1,42 & 4,83 & 6,85 & $\begin{array}{c}\text { Prioritas Sangat } \\
\text { Tinggi }\end{array}$ \\
\hline & $\begin{array}{l}\text { Pengolahan } \\
\text { Arsip Menjadi } \\
\text { Informasi } \\
\end{array}$ & 1,2 & 4,5 & 5,4 & Prioritas Tinggi \\
\hline
\end{tabular}

Sumber: Data Primer, 2021.

mengindikasikan bahwa kompetensi tersebut rata-rata sudah dikuasai dengan baik oleh arsiparis dan telah menjadi bagian dalam rutinitas kerja, hal tersebut sejalan sebagaimana fungsi ASN yang tertuang dalam Undang-Undang Republik Indonesia Nomor 5 Tahun 2014 tentang Aparatur Sipil Negara pasal 10 huruf c yang menyatakan bahwa ASN berfungsi sebagai perekat dan pemersatu bangsa dan memiliki tugas mempererat persatuan dan kesatuan Negara Kesatuan Republik Indonesia (NKRI).

Lebih detail mengenai kompetensi manajerial dan teknis yang termasuk kriteria prioritas sangat tinggi dijelaskan dalam hal berikut, pertama, subkompetensi Integritas. Integritas sendiri merupakan kemampuan untuk berperilaku selaras dengan nilai, norma, dan etika organisasi secara konsisten serta memiliki tanggung jawab terhadap setiap tindakan maupun keputusan yang diambil. Tentunya ini merupakan kompetensi vital yang perlu dimiliki arsiparis dalam menjalankan tugasnya dan memengaruhi juga terhadap kinerjanya. Sejalan dengan deskripsi tersebut, hasil penelitian oleh Yolanda dan Samsir (2020:76) menyatakan Integritas berpengaruh secara signifikan terhadap kinerja individu baik secara parsial maupun simultan. 
Khazanah: Jurnal Pengembangan Kearsipan, 2021, Vol. 14 (2)

Tabel 14

Nilai Prioritas Kompetensi Arsiparis Kriteria Prioritas Sangat Tinggi

\begin{tabular}{|c|c|c|c|}
\hline Jenjang Jabatan & Jenis Kompetensi & Subkompetensi & Prioritas \\
\hline \multirow{5}{*}{ Arsiparis Terampil } & \multirow{4}{*}{ Manajerial } & Integritas & 5,21 \\
\hline & & Kerja Sama & 4,5 \\
\hline & & Orientasi pada Hasil & 5,18 \\
\hline & & Pelayanan Publik & 4,66 \\
\hline & Teknis & $\begin{array}{l}\text { Pengelolaan Arsip } \\
\text { Dinamis }\end{array}$ & 4,51 \\
\hline \multirow{2}{*}{ Arsiparis Mahir } & Manajerial & Orientasi pada Hasil & 7,14 \\
\hline & Teknis & Pengelolaan Arsip Statis & 7,58 \\
\hline \multirow{3}{*}{ Arsiparis Penyelia } & \multirow{3}{*}{ Manajerial } & Kerja Sama & 7,5 \\
\hline & & Komunikasi & 7,83 \\
\hline & & Orientasi pada Hasil & 8 \\
\hline \multirow[t]{2}{*}{ Arsiparis Penyelia } & Manajerial & $\begin{array}{l}\text { Pengembangan Diri dan } \\
\text { Orang Lain }\end{array}$ & 7,8 \\
\hline & Teknis & Pembinaan Kearsipan & 7,33 \\
\hline \multirow{3}{*}{$\begin{array}{l}\text { Arsiparis Ahli } \\
\text { Pertama }\end{array}$} & \multirow{3}{*}{ Manajerial } & Integritas & 3,33 \\
\hline & & Komunikasi & 3,33 \\
\hline & & Pelayanan Publik & 4,17 \\
\hline \multirow{2}{*}{ Arsiparis Ahli Muda } & \multirow{2}{*}{ Teknis } & Pengelolaan Arsip Statis & 7,5 \\
\hline & & Pembinaan Kearsipan & 6,85 \\
\hline
\end{tabular}

Sumber: Data Primer, 2021.

Kedua, subkompetensi Kerja Sama. Kerja sama yang dimaksud disini adalah keterampilan dalam membina dan menjalin hubungan kerja secara efektif dalam rangka optimalisasi sumber daya yang ada dalam penyelesaian tugas dan pencapaian tujuan strategis organisasi. Hal ini sejalan dengan yang diungkapkan Hasbiyadi (2018:10) yang menyatakan bahwa kompetensi kerjasama memiliki berpengaruh signifikan terhadap kinerja organisasi. Kerja sama mampu meningkatkan kinerja organisasi, ditunjukkan dengan adanya intensitas komunikasi yang tinggi sesama pegawai sehingga pegawai mampu menyampaikan atau membagi informasi relevan dan berguna sesama anggota tim.

Ketiga, s u b k o m pete n s i Komunikasi. Komunikasi sendiri adalah keterampilan dalam membangun, membina, dan mempertahankan hubungan kerja secara efektif. Pentingnya kompetensi komunikasi dimiliki karena erat kaitannya dengan kinerja pegawai. Hal tersebut sejalan seperti yang diungkapkan Ardiansyah (2017:27) bahwa komunikasi dapat meningkatkan kepuasan kerja karyawan.

Keempat, subkompetensi Orietasi pada Hasil. Orietasi pada Hasil merupakan suatu kemampuan dalam 
penyelesaian tugas dengan mempertahankan komitmen pribadi yang tinggi, bertanggung jawab, dan dapat diandalkan. Orientasi pada Hasil dapat diartikan pula sebagai kemampuan untuk menetapkan suatu sasaran dan mencapainya, hal ini berdampak positif seperti yang dinyatakan dalam penelitian Amah, et al. (2013:57) bahwa dengan adanya sasaran dapat memberikan motivasi bagi individu untuk mencapai kinerja yang lebih baik serta menunjukkan seberapa efektif individu tersebut.

Kelima, subkompetensi Pelayanan Publik. Pelayanan Publik merupakan keterampilan dalam menjalankan tugastugas pemerintahan secara profesional dalam memenuhi kebutuhan pelayanan publik sesuai dengan standar pelayanan yang netral, objektif, dan tidak diskriminatif. Pelayanan Publik menjadi penting karena memiliki dampak langsung terhadap dan memengaruhi tingkat kepuasan masyarakat, hal ini sejalan seperti yang diungkapkan Indriani, et al. (2017:17) dari hasil penelitiannya yang menyatakan bahwa pelayanan publik dapat meningkatkan kepuasan masyarakat, semakin optimal pelayanan publik yang disediakan maka akan semakin tinggi kepuasan masyarakat.

Keenam, subkompetensi Pengembangan Diri dan Orang Lain. Pengembangan Diri dan Orang Lain merupakan kemampuan untuk dapat melakukan peningkatan pengetahuan dan keterampilan diri serta mampu membantu individu lain untuk meningkatkan potensi dirinya.

Selanjutnya, kompetensi teknis yang terdiri dari Pengelolaan Arsip Dinamis, Pengelolaan Arsip Statis, dan Pembinaan Kearsipan. Pertama, subkompetensi Pengelolaan Arsip Dinamis. Pengelolaan Arsip Dinamis adalah kemampuan melakukan proses penciptaan, penggunaan, dan pemeliharaan, serta penyusutan arsip yang dilakukan terhadap arsip aktif, arsip inaktif dan arsip vital, secara efisien, efektif, dan sistematis. Pengelolaan Arsip Dinamis menjadi penting karena mayoritas arsip yang dimiliki Kemensetneg merupakan arsip dinamis.

Kedua, subkompetensi Pengelolaan Arsip Statis. Pengelolaan Arsip Statis sendiri adalah kemampuan mengendalikan arsip statis secara efisien, efektif, dan sistematis meliputi kegiatan akuisisi, pengolahan, preservasi, pemanfaatan, pendayagunaan, dan pelayanan publik dalam suatu sistem kearsipan nasional. Pengelolaan Arsip Statis memiliki nilai prioritas yang tinggi dikarenakan jenjang jabatan Arsiparis Mahir dan Arsiparis Ahli Muda tidak semuanya berada di Unit Kearsipan I. Berdasarkan Permensesneg Nomor 1 Tahun 2020 tentang Petunjuk Pelaksanaan Pengelolaan Arsip Kementerian 
Sekretariat Negara dinyatakan bahwa tugas menyerahkan arsip statis hanya ada di Unit Kearsipan I. Adapun komposisi Arsiparis Mahir dan Arsiparis Ahli Muda yang ada di Unit Kearsipan I masingmasing hanya berjumlah satu orang dan sisanya ada di Unit Kearsipan II dan III. Hal tersebut tentunya sangat wajar jika mayoritas arsiparis menjadi kurang kompeten di bidang tersebut karena memang tidak menangani arsip statis secara langsung dalam kesehariannya bekerja. Oleh karena itu, agar diperoleh hasil yang optimal diperlukan pelatihan secara tepat dalam hal tersebut dibarengi dengan mutasi secara periodik ke Unit Kearsipan I, sehingga arsiparis dapat mempraktikan pengetahuan dan keterampilan yang diperoleh dari pelatihan dalam pekerjaan sehari-harinya.

Ketiga, subkompetensi Pembinaan Kearsipan. Pembinaan Kearsipan merupakan kemampuan dalam mengarahkan, menguatkan, dan memberdayakan yang berkenaan dengan arsip kepada pencipta arsip, lembaga kearsipan, dan sumber daya manusia kearsipan serta para pemangku kepentingan lainnya, untuk mencapai tujuan penyelenggaraan kearsipan yang optimal dan efektif. Pembinaan Kearsipan menjadi kompetensi yang penting dimiliki arsiparis sebagai bagian dari cara untuk meningkatkan kesadaran dan memengaruhi pihak-pihak terkait dalam mengelola arsip secara lebih baik, tidak lagi dipandang sebelah mata. Selain meminimalisir kendala-kendala yang dihadapi sebagaimana yang diungkapkan Kurniatun (2018:19) bahwa kendala terbesar yang dihadapi pengelolaan arsip adalah rendahnya kesadaran terhadap makna pentingnya arsip. Hal ini berdampak pada pengelolaan arsip yang tidak baik, sarana yang tidak tepat, dan pemeliharaan arsip menjadi terbengkalai. Kekurangan-kekurangan ini berpotensi menimbulkan kerusakan fisik pada arsip bahkan memungkinkan hilangnya informasi yang terdapat dalam arsip tersebut.

\section{Perancangan Pelatihan}

B e rdasarkan prioritas pengembangan kompetensi yang telah dibahas sebelumnya, pesertanya, materi pelatihannya, dan durasi pelaksanaanya dalam bentuk jam pelajaran (JP). Berdasarkan kompetensi yang diprioritaskan untuk diberikan pelatihan maka dirancang beberapa bentuk pelatihan antara lain seperti pada Tabel 15 .

Adapun pemilihan materi pada rancangan pelatihan berdasarkan pada indikator dari masing-masing kompetensi yang perlu dimiliki oleh arsiparis. 
Tabel 15

Rancangan Pelatihan

\begin{tabular}{|c|c|c|c|c|c|}
\hline \multirow{2}{*}{ Peserta } & \multirow{2}{*}{ Jenis Kompetensi } & Sub & \multirow{2}{*}{$\begin{array}{l}\text { Nama } \\
\text { Pelatihan }\end{array}$} & \multirow{2}{*}{ Materi Pelatihan } & \multirow{2}{*}{ Durasi } \\
\hline & & kompetensi & & & \\
\hline \multirow[b]{2}{*}{$\begin{array}{l}\text { Arsiparis } \\
\text { Terampil }\end{array}$} & \multirow[b]{2}{*}{ Manajerial } & \multirow[b]{2}{*}{ Integritas } & \multirow[b]{2}{*}{$\begin{array}{l}\text { Membangun } \\
\text { Integritas }\end{array}$} & $\begin{array}{l}\text { Memahami dan mengenali } \\
\text { perilaku sesuai kode etik }\end{array}$ & - $3 \mathrm{JP}$ \\
\hline & & & & $\begin{array}{l}\text { Komunikasi Efektif dalam } \\
\text { penyampaian Kode Etik/Nilai } \\
\text { Organisasi }\end{array}$ & $\cdot 5 \mathrm{JP}$ \\
\hline \multirow{3}{*}{$\begin{array}{l}\text { Arsiparis } \\
\text { Terampil }\end{array}$} & \multirow{3}{*}{ Manajerial } & \multirow{3}{*}{ Kerja Sama } & \multirow{3}{*}{$\begin{array}{l}\text { Bekerja dalam } \\
\text { Tim }\end{array}$} & Konsep bekerja dalam tim & - $2 \mathrm{JP}$ \\
\hline & & & & Komunikasi efektif dalam Tim & - $3 \mathrm{JP}$ \\
\hline & & & & Komitmen kerja & - $3 \mathrm{JP}$ \\
\hline \multirow{3}{*}{$\begin{array}{l}\text { Arsiparis } \\
\text { Terampil }\end{array}$} & \multirow{3}{*}{ Manajerial } & \multirow{3}{*}{$\begin{array}{l}\text { Orientasi pada } \\
\text { Hasil }\end{array}$} & \multirow{3}{*}{ Bekerja Efektif } & Get Things Done & - $3 \mathrm{JP}$ \\
\hline & & & & Implementasi Standar Kualitas & $\cdot 2 \mathrm{JP}$ \\
\hline & & & & Growth Mindset & - $3 \mathrm{JP}$ \\
\hline \multirow{3}{*}{$\begin{array}{l}\text { Arsiparis } \\
\text { Terampil }\end{array}$} & \multirow{3}{*}{ Manajerial } & \multirow{3}{*}{ Pelayanan Publik } & \multirow{3}{*}{ Pelayanan Prima } & Standar Pelayanan & $\cdot 2 \mathrm{JP}$ \\
\hline & & & & Service Excellence & $\cdot 2 \mathrm{JP}$ \\
\hline & & & & Komunikasi proaktif & • $4 \mathrm{JP}$ \\
\hline \multirow{4}{*}{$\begin{array}{l}\text { Arsiparis } \\
\text { Terampil }\end{array}$} & \multirow{4}{*}{ Teknis } & \multirow{4}{*}{$\begin{array}{l}\text { Pengelolaan Arsip } \\
\text { Dinamis }\end{array}$} & \multirow{4}{*}{$\begin{array}{l}\text { Pengelolaan } \\
\text { Arsip Dinamis }\end{array}$} & Jadwal Retensi Arsip(JRA) & - $5 \mathrm{JP}$ \\
\hline & & & & $\begin{array}{l}\text { Pengantar Pengelolaan Arsip } \\
\text { Dinamis }\end{array}$ & - $3 \mathrm{JP}$ \\
\hline & & & & Pengelolaan Arsip Aktif & - $4 \mathrm{JP}$ \\
\hline & & & & Pengelolaan Arsip Inaktif & - $4 \mathrm{JP}$ \\
\hline \multirow{3}{*}{$\begin{array}{l}\text { Arsiparis } \\
\text { Mahir }\end{array}$} & \multirow{3}{*}{ Manajerial } & \multirow{3}{*}{$\begin{array}{l}\text { Orientasi pada } \\
\text { Hasil }\end{array}$} & \multirow{3}{*}{$\begin{array}{l}\text { Penetapan } \\
\text { Tujuan }\end{array}$} & Konsep penetapan Tujuan & - $3 \mathrm{JP}$ \\
\hline & & & & & \\
\hline & & & & Peningkatan Proses Bisnis & $\cdot 5 \mathrm{JP}$ \\
\hline & & Pengelolaan Arsip & & Penyusunan daftar arsip statis & - $4 \mathrm{JP}$ \\
\hline Mahir & Teknis & Statis & Arsip Statis & $\begin{array}{l}\text { Teknik identifikasi fisik arsip } \\
\text { statis }\end{array}$ & • $4 \mathrm{JP}$ \\
\hline & & & & Teknik membangun tim efektif & - $6 \mathrm{JP}$ \\
\hline $\begin{array}{l}\text { Arsiparis } \\
\text { Penyelia }\end{array}$ & Manajerial & Kerja Sama & $\begin{array}{c}\text { Membangun Tim } \\
\text { Efektif }\end{array}$ & Negosiasi dan Lobbying & $\bullet 6 \mathrm{JP}$ \\
\hline & & & & Membangun Jejaring & - $6 \mathrm{JP}$ \\
\hline & & & & Komunikasi Efektif & $\cdot 5 \mathrm{JP}$ \\
\hline $\begin{array}{l}\text { Arsiparis } \\
\text { Penyelia }\end{array}$ & Manajerial & Komunikasi & Komunikasi & Presentasi Efektif & $\cdot 5 \mathrm{JP}$ \\
\hline & & & & Penulisan Laporan Efektif & • $6 \mathrm{JP}$ \\
\hline & & & Penetapan & Konsep penetapan Tujuan & - $3 \mathrm{JP}$ \\
\hline $\begin{array}{l}\text { Arsiparis } \\
\text { Penvelia }\end{array}$ & Manajerial & $\begin{array}{c}\text { Orientasi pada } \\
\text { Hasil }\end{array}$ & Tujuan dan & Peningkatan Proses Bisnis & $\cdot 5 \mathrm{JP}$ \\
\hline & & & Umpan Balik & Teknik memberi umpan balik & - $8 \mathrm{JP}$ \\
\hline & & & & Objective Key Result & • $4 \mathrm{JP}$ \\
\hline $\begin{array}{l}\text { Arsiparis } \\
\text { Penyelia }\end{array}$ & Manajerial & $\begin{array}{c}\text { Pengembangan Diri } \\
\text { dan Orang Lain }\end{array}$ & $\begin{array}{c}\text { People } \\
\text { Development }\end{array}$ & Teknik memberi umpan balik & - $6 \mathrm{JP}$ \\
\hline & & & & Teknik Coaching Efektif & - $6 \mathrm{JP}$ \\
\hline
\end{tabular}


Khazanah: Jurnal Pengembangan Kearsipan, 2021, Vol. 14 (2)

\begin{tabular}{|c|c|c|c|c|c|}
\hline \multirow{3}{*}{$\begin{array}{l}\text { Arsiparis } \\
\text { Penyelia }\end{array}$} & \multirow{3}{*}{ Teknis } & \multirow{3}{*}{$\begin{array}{l}\text { Pembinaan } \\
\text { Kearsipan }\end{array}$} & \multirow{3}{*}{$\begin{array}{l}\text { Pembinaan } \\
\text { Kearsipan }\end{array}$} & Bimbingan Teknis Kearsipan & $\cdot 4 \mathrm{JP}$ \\
\hline & & & & Metode Presentasi Kearsipan & - $4 \mathrm{JP}$ \\
\hline & & & & $\begin{array}{c}\text { Metode Penelitian dan } \\
\text { Penulisan Ilmiah Kearsipan }\end{array}$ & - $4 \mathrm{JP}$ \\
\hline \multirow[b]{2}{*}{$\begin{array}{l}\text { Arsiparis Ahli } \\
\text { Pertama }\end{array}$} & \multirow[b]{2}{*}{ Manajerial } & \multirow[b]{2}{*}{ Integritas } & \multirow[b]{2}{*}{$\begin{array}{l}\text { Membangun } \\
\text { Integritas }\end{array}$} & $\begin{array}{l}\text { Memahami dan mengenali } \\
\text { perilaku sesuai kode etik }\end{array}$ & - $3 \mathrm{JP}$ \\
\hline & & & & $\begin{array}{l}\text { Komunikasi Efektif dalam } \\
\text { penyampaian Kode Etik/Nilai } \\
\text { Organisasi }\end{array}$ & $\cdot 5 \mathrm{JP}$ \\
\hline \multirow{2}{*}{$\begin{array}{l}\text { Arsiparis Ahli } \\
\text { Pertama }\end{array}$} & \multirow{2}{*}{ Manajerial } & \multirow{2}{*}{ Komunikasi } & \multirow{2}{*}{ Komunikasi } & Komunikasi Efektif & - $4 \mathrm{JP}$ \\
\hline & & & & Penulisan Laporan Efektif & - $4 \mathrm{JP}$ \\
\hline \multirow{4}{*}{$\begin{array}{l}\text { Arsiparis Ahli } \\
\text { Pertama }\end{array}$} & \multirow{4}{*}{ Manajerial } & \multirow{4}{*}{ Pelayanan Publik } & \multirow{4}{*}{ Pelayanan Prima } & $\begin{array}{l}\text { Komitmen pelayanan yang } \\
\text { prima }\end{array}$ & $\cdot 1 \mathrm{JP}$ \\
\hline & & & & $\begin{array}{l}\text { Service Excellence dan } \\
\text { kerjasama kelompok }\end{array}$ & $\cdot 2 \mathrm{JP}$ \\
\hline & & & & Memahami pelanggan & $\cdot 2 \mathrm{JP}$ \\
\hline & & & & Komunikasi proaktif & - $3 \mathrm{JP}$ \\
\hline \multirow{5}{*}{$\begin{array}{l}\text { Arsiparis Ahli } \\
\text { Muda }\end{array}$} & \multirow{5}{*}{ Teknis } & \multirow{5}{*}{$\begin{array}{l}\text { Pengelolaan Arsip } \\
\text { Statis }\end{array}$} & \multirow{5}{*}{$\begin{array}{l}\text { Pengelolaan } \\
\text { Arsip Statis }\end{array}$} & $\begin{array}{r}\text { Teknik penataan dan } \\
\text { penyimpanan arsip statis }\end{array}$ & - $4 \mathrm{JP}$ \\
\hline & & & & $\begin{array}{l}\text { Teknik identifikasi khazanah } \\
\text { arsip dan rencana teknis } \\
\text { penyusunan daftar arsip statis }\end{array}$ & $\cdot 4 \mathrm{JP}$ \\
\hline & & & & $\begin{array}{l}\text { Teknik penelusuran sumber } \\
\text { data dan referensi daftar arsip } \\
\text { statis }\end{array}$ & $\cdot 4 \mathrm{JP}$ \\
\hline & & & & $\begin{array}{l}\text { Penyusunan skema sementara } \\
\text { daftar arsip statis }\end{array}$ & - $4 \mathrm{JP}$ \\
\hline & & & & $\begin{array}{l}\text { Penyusunan skema definitif } \\
\text { daftar arsip statis }\end{array}$ & $\cdot 4 \mathrm{JP}$ \\
\hline \multirow{6}{*}{$\begin{array}{l}\text { Arsiparis Ahli } \\
\text { Muda }\end{array}$} & \multirow{6}{*}{ Teknis } & \multirow{6}{*}{$\begin{array}{l}\text { Pembinaan } \\
\text { Kearsipan }\end{array}$} & \multirow{6}{*}{$\begin{array}{l}\text { Pembinaan } \\
\text { Kearsipan }\end{array}$} & $\begin{array}{l}\text { Bimbingan Teknis, Supervisi } \\
\text { dan Pengawasan Kearsipan }\end{array}$ & $\cdot 4 \mathrm{JP}$ \\
\hline & & & & Telaah NSPK Kearsipan & $\cdot 4 \mathrm{JP}$ \\
\hline & & & & Penyusunan Manual Kearsipan & $\cdot 4 \mathrm{JP}$ \\
\hline & & & & Metode Presentasi Kearsipan & - $4 \mathrm{JP}$ \\
\hline & & & & $\begin{array}{l}\text { Training of Trainer } \\
\text { Kearsipan }\end{array}$ & $\cdot 4 \mathrm{JP}$ \\
\hline & & & & $\begin{array}{c}\text { Metode Penelitian dan } \\
\text { Penulisan Ilmiah Kearsipan }\end{array}$ & - $4 \mathrm{JP}$ \\
\hline
\end{tabular}

Sumber: Data Primer, 2021.

\section{SIMPULAN}

Dari keseluruhan analisis dan diskusi yang telah dijabarkan, maka dapat disimpulkan. Pertama, level kompetensi yang dibutuhkan arsiparis Kemensetneg berkisar di level 4 sampai dengan 5 atau termasuk kategori mumpuni sampai dengan ahli, meliputi jenis kompetensi manajerial, sosial kultural, dan teknis. Kedua, level kompetensi yang dimiliki arsiparis Kemensetneg berkisar di level 3 sampai dengan 4 atau termasuk kategori 
mumpuni sampai dengan ahli, meliputi jenis kompetensi manajerial, sosial kultural, dan teknis. Kedua, level kompetensi yang dimiliki arsiparis Kemensetneg berkisar di level 3 sampai dengan 4 atau termasuk kategori menengah sampai dengan mumpuni, meliputi jenis kompetensi manajerial, sosial kultural, dan teknis. Ketiga, terdapat kesenjangan yang signifikan di semua jenis kompetensi baik itu kompetensi manajerial, sosial kultural maupun teknis, dengan besaran kesenjangan level kompetensi berkisar antara 0,13 sampai dengan 1,73 . Keempat, Program pelatihan yang dirancang sesuai dengan kebutuhan arsiparis dengan memperhatikan hasil analisis kesenjangan dan prioritas pengembangan kompetensi adalah: Arsiparis Terampil diberikan Pelatihan Membangun Integritas, Pelatihan Bekerja dalam Tim, Pelatihan Bekerja Efektif, Pelatihan Pelayanan Prima dan Pelatihan Pengelolaan Arsip Dinamis. Arsiparis Mahir diberikan Pelatihan Penetapan Tujuan dan Pelatihan Pengelolaan Arsip Statis. Arsiparis Penyelia diberikan Pelatihan Membangun Tim Efektif, Pelatihan Komunikasi, Pelatihan Penetapan Tujuan dan Umpan Balik, Pelatihan People Development dan Pelatihan Pembinaan Kearsipan. Arsiparis Ahli Pertama diberikan pelatihan Pelatihan Membangun Integritas, Pelatihan Komunikasi dan Pelatihan Pelayanan Prima. Arsiparis Ahli Muda diberikan pelatihan Pelatihan Pengelolaan Arsip Statis dan Pelatihan Pembinaan Kearsipan.

Rekomendasi yang dapat diberikan dan ditindaklanjuti dengan mencermati beberapa simpulan di atas adalah sebagaimana berikut. Pertama, perlu dibuat pelatihan berdasarkan analisis kebutuhan pelatihan dengan memperhatikan kesenjangan, level dan jenis kompetensi yang dimiliki arsiparis sehingga dapat memenuhi standar kompetensinya; kedua, prioritas penyelenggaraan pelatihan yang perlu segera dilaksanakan mengacu pada prioritas pengembangan kompetensi berdasarkan analisis kesenjangan kompetensi; ketiga, perlu dilakukan reassessment kompetensi secara berkala untuk memonitor perubahan kompetensi yang dimiliki arsiparis; terakhir, perlu adanya sinergi pihak pusat pendidikan dan pelatihan (Pusdiklat), Unit Kearsipan I Kemensetneg, Arsip Nasional Republik Indonesia (ANRI) dalam rangka mengembangkan pelatihan yang tepat sasaran dan variatif untuk memenuhi pengembangan kompetensi arsiparis. 


\section{DAFTAR PUSTAKA}

\section{Buku dan Jurnal}

Amah E, Christine AN, \& Nwakaego C. (2013). Result Oriented Target Setting and Leading High Performance Teams. Industrial Engineering Letters, 3(9), 47-59.

Ardiansyah, DO. (2017). Pengaruh Komunikasi terhadap Kinerja Karyawan dengan Dimediasi oleh Kepuasan Kerja (Studi pada Bagian Produksi Pabrik Kertas PT. Setia Kawan Makmur Sejahtera Tulungagung). Jurnal Bisnis dan Manajemen, 3(1), 16-30.

Ghozali, I. (2011). Aplikasi Analisis Multivariate Dengan Program IBM SPSS 19. Semarang: Badan Penerbit Universitas Diponegoro.

Goldstein I. L., \& Ford, J. K. (2002). Training in Organizations: Needs Assessment, Development, and Evaluation $\left(4^{\text {th }}\right.$ ed). Belmont, CA: Wadsworth.

Hasbiyadi. (2018). Pengaruh Kompetensi Kerjasama Tim dan Kepemimpinan melalui Komitmen Organisasional terhadap Kinerja Perusahaan pada BUMN di Kota Makassar. Bongaya Journal for Research in Management, 1(1), 1-13.

Indriani, D., Sugeng, R., \& Agung S. (2017). Pengaruh Pelayanan Publik terhadap Kepuasan Masyarakat: Studi Kasus Izin Produksi Pangan Industri Rumah Tangga di Kantor Badan Penanaman Modal Kota Batu. Jurnal Ilmu Sosial dan Ilmu Politik Universitas Tribhuwana
Tunggadewi, 6(2), 10-17.

Kurniatun. (2018). Pembinaan Arsip Unit Kerja Sebagai upaya Penyelamatan Arsip. Diplomatika, 2(1), 9-22.

Noe, R.A, Hollenbeck, J.R, Gerhart, B., \& Wright, P.M. (2010). Human Resource Management: Gaining a Competitive Advantage ( $7^{\text {th }}$ edition). Boston: McGrawHill.

Palan, R. (2007). Competency Management: Teknik Mengimplementasikan Manajemen SDM Berbasis Kompetensi untuk Meningkatkan Daya Saing Organisasi. Jakarta: PPM.

Soetadikaria, R.A.A.Q. (2017). Analisis Kebutuhan Pelatihan Tenaga Perpustakaan di Instistut Pertanian Bogor. Tesis. Program Pascasarjana Magister Manajemen dan Bisnis IPB, Bogor.

Sugiyono. (2010). Metode Penelitian Bisnis. Bandung: Alfabeta.

Sutrisno, Edy. (2009). Manajemen Sumber Daya Manusia (Edisi Pertama). Jakarta: Kencana Prenada Media Group.

Yolanda, N.M., \& Syamsir, S. (2020). Pengaruh Integritas terhadap Kinerja Pegawai Negeri Sipil (PNS) di Lingkungan Organisasi Perangkat Daerah (OPD) Dinas Kota Padang. Jurnal Perspektif, 3(1), 70-77.

\section{Produk Hukum}

Undang-Undang Republik Indonesia Nomor 5 Tahun 2014. Aparatur Sipil Negara. Lembaran Negara 
Republik Indonesia. Jakarta.

Peraturan Pemerintah Nomor 11 Tahun 2017. Manajemen Pegawai Negeri Sipil. Lembaran Negara Republik Indonesia. Jakarta.

Peraturan Menteri Pendayagunaan Aparatur Negara dan Reformasi Birokrasi Nomor 38 Tahun 2017. Standar Kompetensi Jabatan Aparatur Sipil Negara. $\mathrm{K}$ e menteria $\mathrm{n}$ e n teri Pendayagunaan Aparatur Negara dan Reformasi Birokrasi. Jakarta.

Peraturan Menteri Sekretaris Negara Nomor 1 Tahun 2020. Petunjuk Pelaksanaan Pengelolaan Arsip Kementerian Sekretariat Negara. Kementerian Sekretaris Negara. Jakarta. 